\title{
THE CLASS ACTION DEVICE IN ANTISEGREGATION CASES
}

The last several years have seen an increase in the number of suits brought in the federal courts to complain of the denial to minority groups of certain claimed constitutional guarantees. The conduct complained of is labelled "discriminatory"- the refusal, by or under color of state authority, to allow a "minority" group the use of certain facilities or the enjoyment of certain privileges which, it is urged, must be available for the benefit of all citizens equally. Many such actions are brought under Federal Rule 23, or similar state rules, ${ }^{1}$ in behalf of all the members of the affected group, rather than in the sole behalf of plaintiffs actually before the court. The relevant portions of Rule 23 provide:

(a) REPRESENTATION. If persons constituting a class are so numerous as to make it impracticable to bring them all before the court, such of them, one or more, as will fairly insure the adequate representation of all may, on behalf of all, sue or be sued, when the character of the right sought to be enforced for or against the class is

(1) joint, or common, or secondary in the sense that the owner of a primary right refuses to enforce that right and a member of the class thereby becomes entitled to enforce it; . . . or

(3) several, and there is a common question of law or fact affecting the several rights and a common relief is sought.

Taking the viewpoint of plaintiffs' counsel, the aim of this comment is to discuss the difficulties and advantages of using the class action device in "antisegregation" litigation. Segregation is herein used to mean any policy of discriminatory treatment of a minority group.

\section{I}

An obvious point should be noted at the outset, namely, that segregation is a group phenomenon. Although the effects of discrimination are felt by each member of the group, any discriminatory practice is directed against the group as a unit and against individuals only as their connection with the group invokes the antigroup sanction. Negro students in the South are provided with separate school facilities because they possess ascertainable characteristics common to other persons which enable legislatures to promulgate laws solely in terms of those characteristics. Similarly, the use of public swimming facilities in some southwestern cities is forbidden to persons of Mexican or Indian origin on a group-identification basis. If segregration is a wrong, it is a group wrong, and the mode of redress must be group-wide to be adequate.

1 For a review of the state law before the Federal Rules were promulgated see Wheaton, Representative Suits Involving Numerous Litigants, 19 Cornell L.Q. 399 (1934). After promulgation of the Rules, several states adopted the provisions of Rule 23. See, e.g., Ariz. Code Ann. (1939) \$§ 21-524 through 21-526; Ark. Stat. Ann. (1947) § 27-809; Colo. Stat. Ann. (1935), Rules of Civil Procedure, Rule 23; Delaware, Rules of Court of Chancery, Rule 23; Code of Iowa (1950), Rules of Civil Procedure $\$ 42 ;$ N.M. Stat. Ann. (1941), Rules of Civil Procedure, $\$ 23$. (In New Mexico, however, the old class action rule also remains in effect.) 
One reason that the class action appears to be an advantageous method of securing relief for the group is that a favorable decree will in its terms apply to all members. ${ }^{2} \mathrm{~A}$ decree rendered in an action brought by an individual on grounds that he is being discriminated against will require the defendant to desist from such practices only where the individual is concerned. The position of the group will improve only if compliance with the decree by the defendant incidentally inures to the benefit of all members. But a decree rendered in a class action will benefit directly the group as a unit.

Although the law is not settled on this question, ${ }^{3}$ a second advantage of the class suit in racial discrimination cases may be that any one of the members of the class can ask enforcement of a favorable decree. ${ }^{4}$ If the decree, although by its terms restraining discrimination against any person in the group, could be enforced only by the class representative named in the original action, its effectiveness would be limited. For example, the decree would be enforceable only while the named plaintiff is still alive. Further, the named plaintiff might leave the jurisdiction and not be disposed to return to seek enforcement of a decree which would no longer concern him; or, even if alive and in the jurisdiction, the named plaintiff may not desire to ask enforcement of the decree. Finally, it is even doubtful whether the named representative can ask enforcement of the decree in behalf of others of his class if the decree has been complied with where he himself is concerned. ${ }^{5}$ If the group nature of the remedy is to be made reciprocal to the group nature of the wrong, any member of the class to whom the decree applies should have standing to demand its enforcement. The right of unnamed members of a class to seek enforcement of a decree is treated more fully in part III below.

In view of the group nature of the wrong, the problem of mootness may be a serious one where an individual sues in his own name only. Once the suit is begun, the defendants may decide to alter their treatment of the individual plaintiff

${ }^{2}$ The language in Thomas v. Hibbitts, 46 F. Supp. 368, 371 (D.C. Tenn., 1942), is typical: "Plaintiff is entitled, in his own behalf and in behalf of the class whom he represents, to the issuance of an injunction restraining the defendant Board of Education, its officers, agents and employees, from making any discrimination against plaintiff and the class whom he represents in fixing salaries to be paid to school teachers for the next fiscal year and succeeding years on the grounds of race or color." In Elmore v. Rice, 72 F. Supp. 516, 528 (D.C. S.C., 1947), aff'd, 165 F. 2d 387 (C.A. 4th, 1947), the district court said, "The prayer of the complaint for a declaratory judgment will therefore be granted by which it will be adjudged that the plaintiff and others similarly situated are entitled to be enrolled and to vote in the primaries .... and the defendants and their successors in office will be enjoined from excluding qualified voters from enrollment and casting ballots by reason of their not being persons of the white race."

${ }^{3}$ See part III infra for a discussion of enforceability.

1 In Wilson v. City of Paducah, 100 F. Supp. 116 (D.C. Ky., 1951), a motion by a member of the class, who was not named in the original complaint, to intervene after judgment and ask for an injunction was granted.

${ }^{5}$ Because the question would be moot, i.e., there would be no controversy between the named plaintiff and the defendant. See discussion, pages 579-80 infra, on Gray v. Board of Trustees, 342 U.S. 517 (1952). 
rather than have their general policy of segregation put to the test of litigation. ${ }^{6}$ The individual plaintiff may be admitted to the municipal swimming facilities or to the state law school in order to block a court determination of the issue. Moreover, in the ordinary school segregation case, the plaintiff may literally graduate out of being entitled to relief if, by the time the final decision is ready, he has completed his matriculation. Bibb v. Mayor of Alton is a ready example. In that case, nine years' time was required before the Supreme Court of Illinois finally ordered that the plaintiffs be admitted to the public school system on a nonsegregated basis. ${ }^{7} \mathrm{Had}$ the plaintiffs been over school age at the time of the last appeal, the order would probably not have issued because there would have been no controversy between the parties.

There is some doubt whether the same result would obtain if an action is brought for the benefit of an entire class. The Court of Appeals for Eighth Circuit has held that before a class action can be dismissed, there must be some evidence of permanent abandonment of the discriminatory policy complained of. ${ }^{8}$ The court in Morris v. Williams ${ }^{9}$ said that one reason the action would not be dismissed on the claim of defendants' counsel that the discriminatory salary schedule had been replaced by a nondiscriminatory schedule was that "there is no assurance ... that such usage and custom may not be resumed at any time, even though presently abandoned." 10 The court recognized that the harm sought to be corrected by the litigation was discrimination against a group, and hence held that the action could not be dismissed until there had been a decision on the merits. The court believed that the controversy could not be said to be moot until it was clear that over-all discriminatory practices had been abolished.

In Gray v. Board of Trustees, ${ }^{11}$ a recent Supreme Court case, a somewhat different situation was presented. The plaintiffs wanted to apply for admission to the University of Tennessee but were refused application blanks, presumably because of University policy against admission of Negroes. They brought an action for themselves and others similarly situated to enjoin the University from denying to Negroes the right of admission. The district court declared that the plaintiffs were entitled to admission to the University, ${ }_{12}^{12}$ but declined to issue an

- Just the opposite might very well be true. Defendants may be anxious to have a court determination in order to have the legality of their policy settled, particularly if they believe the decision would be in their favor.

7 The action was remanded on the first appeal, the court holding that it had been improper for the trial court to exclude evidence of the general nature of the discrimination. 179 Ill. 615, 54 N.E. 421 (1899). The Illinois Supreme Court reversed three more verdicts for the defendants on the grounds that the verdicts were against the weight of the evidence. 193 Ill. 309, 61 N.E. 1077 (1901); 209 IIl. 461 , 70 N.E. 640 (1904); 221 Ill. 275,77 N.E. 429 (1906). After another verdict for defendants, the court granted plaintiffs the relief they asked without a jury verdict, on the grounds that the evidence was clearly in plaintiffs' favor. 233 Ill. 542, 84 N.E. 664 (1908).

${ }^{8}$ Morris v. Williams, 149 F. 2d 703 (C.A. 8th, 1945).

9 Ibid. $\quad{ }^{10}$ Ibid., at 709.

11342 U.S. 517 (1952).

12 Gray v. University of Tennessee, 97 F. Supp. 463 (D.C. Tenn., 1951). 
order because it believed "that the University authorities will either comply with the law as herein stated or take the case up on appeal. ..."13 The plaintiffs appealed the case in order to obtain a favorable decree, ${ }^{14}$ but before the case reached the Supreme Court, they were granted admission to the University. The Supreme Court held that the substantive issue could not then be decided because "appellants requests for admission to the University of Tennessee have been granted and ... there is no indication that any person 'similarly situated' will not be afforded the same treatment. ..."15 This result seems questionable. In dismissing the action because of mootness, the Court relied on the fact that the original complainants had been admitted to the University. What the plaintiffs challenged by bringing the action, however, was the Trustees' policy of refusing admission to Negroes as a group. It would appear, therefore, that the Court should have required a showing that the over-all policy had been abandoned before declaring the issue moot. The action taken by the Trustees in admitting the representative plaintiffs to the University could have been a maneuver calculated to evade a court determination of the legality of their policy. The issue properly submitted was, however, precisely whether the Trustees' broad nonadmission policy as to Negroes was legally objectionable. It is submitted that if an action be brought in behalf of a class, relief as to the individual explicitly named should not have the effect of making the question moot unless the defendants accompany it with assurance that the relief is truly a reflection of a policy change. ${ }^{16}$

Even under the doctrine of the Gray case, there are certain intervention rules which will, to some extent, protect the class from tactics used to avoid a court determination of the constitutionality of the defendants' policies. Although not expressly provided for by Rule 23 , any member of the represented class may intervene as a party to the action. ${ }^{17}$ Whenever there is a threat that the defendants will attempt to alter discriminatory practices vis à vis the representative as a move to make him ineligible to continue prosecution of the action, any member

13 Ibid., at 468 .

${ }^{14}$ Before the trial on the merits, a three-judge court refused to take jurisdiction of the case. 100 F. Supp. 113 (D.C. Tenn., 1951). This refusal was one basis of the appeal to the Supreme Court.

15342 U.S. at 518.

${ }^{16}$ That relief given to the plaintiff in an individual action should have the effect of making the question moot is not disputed. Courts very often decline to decide abstract points of law in the absence of a controversy. The contention is simply that relief to the representatives is not necessarily relief to the class, and a justiciable controversy might exist after the complaints of the representative have been satisfied.

${ }^{17}$ Rule 24(a)(2), Fed. Rules Civ. Proc., provides for intervention of right "when the representation of the applicant's interest by existing parties is or may be inadequate, and the applicant is or may be bound by a judgment in the action. ..." An applicant may be permitted to intervene "when [his] claim or defense and the main action have a question of law or fact in common." Rule 24(b)(2). The members of a class represented in a class action would come under one or the other of these provisions. See System Federation No. 91 v. Reed, 180 F. 2d 991 (C.A. 6th, 1950), discussed pages 590-91 infra. 
of the plaintiff class may intervene and act as representative of the class in place of the original plaintiff. In this way, it can be made more difficult for the defendants to avoid determination of the substantive issue.

In the same way, the liberal intervention provisions which apply to class actions can prevent the dismissal or compromise of an action if, for any reason, the original representative decides not to carry on. If there is a threat of dismissal or compromise, another member of the class can join as plaintiff, and the original representative can then cause a dismissal only as to himself. ${ }^{18}$ The new party would continue to represent the class. Protection is also given to the interests of the class by the provisions of part (c) of Rule $23,{ }^{19}$ which gives the court discretion to require that notice be given to members of the class before the action is dismissed or compromised. The members of the class are thus given the opportunity to intervene. ${ }^{20}$ That part of the rule which makes approval of the court necessary to dismissal or compromise of a class action would, when exercised wisely, prevent either dismissal or compromise detrimental to the best interests of the class.

Another advantage of the class action device in this type of case is that it aids the plaintiffs in showing the seriousness of the discriminatory practice complained of. Use of the device itself carries an implicit declaration that the alleged wrong is general, widespread, and a matter of state policy. Moreover, if the action were brought by an individual only on his own behalf, evidence of the group nature of the wrong might not be relevant. ${ }^{21}$ But in a class suit, evidence of discrimination against any and all members of the class would be admissible, enabling the plaintiff to broaden the nature of his proof and increase the diffculties of rebuttal.

Further, individual plaintiffs asking relief from discriminatory practices might be viewed by the court and by the community as malcontents or eccentrics. The reception given to the commencement of such an action would probably be much better if it were brought in the name of and on behalf of the entire group affected by the segregation. Class representatives would appear not so much as a few plaintiffs with a grudge, but as part of a group with a justifiable claim. Courts also might be reluctant to make such sweeping decisions when

${ }^{18}$ See 3 Moore's Federal Practice 3,553 et seq. (2d ed., 1948).

19 Rule 23(c), Fed. Rules Civ. Proc., reads as follows: "(c) DISMISSAL OR COMPROMISE. A class action shall not be dismissed or compromised without the approval of the court. If the right sought to be enforced is one defined in paragraph (1) of subdivision (a) of this rule notice of the proposed dismissal or compromise shall be given to all members of the class in such manner as the court directs. If the right is one defined in paragraphs (2) or (3) of subdivision (a) notice shall be given only if the court requires it."

${ }^{20}$ It has been held, in a stockholders' derivative action, that one who has been given notice of a proposed dismissal or compromise is a "party" to the proceedings in the sense that he has a right of appeal. Cohen v. Young, 127 F. 2d 721 (C.A. 6th, 1942).

${ }^{21}$ However, in Bibb v. Mayor of Alton, 179 Ill. 615, 54 N.E. 421 (1899), it was held that evidence of widespread discrimination was relevant, although the action was not a class action. 
only an individual complains, because of their far-reaching effects on the established policies of the community.

In order to obtain relief for the entire group without the use of the class action device, it would be necessary for all of the members of the group to join as plaintiffs in the action. Looking at the kinds of groups for which relief is sought in antisegregation litigation, it can be seen at once that it would be an impossible task to organize the members into cohesive groups of parties plaintiff. The primary obstacles are the large number of members in many of the groups, their inaccessibility, and very often their unwillingness to participate in a lawsuit (a venture about which many of the group may know very little), particularly one which does not offer them any monetary gain and might carry with it the burden of considerable expense. At the same time that the class action proceeds toward an end which is to secure to the group its constitutional privileges, it can be an incentive for the participation of all members of the group in a common fight. Those who are conducting the litigation, very often group and community leaders, may use the class suit as a focal point around which to center group participation and interest. Money contributions may be sought, meetings may be called, participation in the organization leading the civil liberties fight may be solicited. Probably, group participation and interest could not be aroused to this extent if the pending or proposed action were brought by individuals asking for private rather than group-wide relief.

A favorable decree in a class action grounded on segregation may, in one sense, be said to force a political judgment on some members of the group involved. The suit is brought in the name of the class and for its apparent benefit by self-constituted class representatives. No referendum need be conducted among the members of the group seeking their approval of the action, but in spite of this the plaintiff is allowed to sue for himself and for "all others similarly situated." The feeling of the majority on the issue posed for decision is, as a factual matter, unknown. The conclusion contended for by the class representative may be one which some members of the class oppose or about which many are indifferent or undecided. Yet the class suit is brought in behalf of all members of the group, and the results of the action will certainly affect them. If, for example, Governor Byrnes can be expected to abandon public education in South Carolina should Plessy v. Ferguson ${ }^{22}$ be overruled, an action brought by the putative class representatives ${ }^{23}$ may lead to a result which many South Carolina Negroes would deem worse than continued segregation. Can it be argued, then, that since continued segregation raises a political as well as a legal issue, the democratic principle of free choice requires that all members of the group affected be given an opportunity to pass upon the question whether the proposed class suit should or should not be brought? And further, should not the class be given

2163 U.S. 537 (1896).

${ }^{23}$ Briggs v. Elliott, 98 F. Supp. 529 (D.C. S.C., 1951), cause remanded, 342 U.S. 350 (1952), decided on remand, 103 F. Supp. 920 (D.C. S.C., 1952), appeal pending, S. Ct. Docket No. 101. 
some choice as to who shall represent them, this being not only a tactical question but also a consideration going to the group's prestige as it is affected by the court's and the community's attitude toward its representatives?

On the other hand, it may be said that most members of a large group are resigned and quiescent in the face of prevailing practice. They may think that any action on their part will be futile, or that active criticism of the status quo may result in retribution against them as individuals. Under these circumstances, it may be that the making of political judgments for an inert and perhaps intimidated group of people is the proper function of the group's leaders. It is also true that any member of the class opposed to the objectives of the class action may actively oppose it by joining as a defendant or appearing as a witness for the defense.

\section{II}

When a constitutional right is set up in behalf of a class, courts ordinarily find no difficulty in allowing use of the class action device. ${ }^{24}$ However, in two recent cases involving alleged discrimination, use of the class suit was held improper.

In Williams $v$. Kansas City, ${ }^{25}$ the plaintiffs sought an injunction restraining the city from denying them and other Negroes "similarly situated" admission to certain municipal swimming facilities. The court stated, as an elementary principle of constitutional law, that "it is the individual who is entitled to equal protection of the law ... [he] alone may complain that his constitutional privilege has been invaded, and he has no standing to sue for the deprivation of similar civil rights of others. ${ }^{26}$ Sweatt v. Painter, ${ }^{27}{ }^{2}$ CCCabe v. Atchison, Topeka \& Santa Fe Railway Company, ${ }^{28}$ and Gaines v. Canada ${ }^{29}$ were cited to support the proposition that the constitutional right to equal protection is a "personal" one, belonging solely to the individual. However, there seems to be little in any of these cases to indicate that the Supreme Court found something so unique about the "personal" nature of a constitutional right that such right must now be held incapable of assertion by a class of individuals. ${ }^{30}$ Further, Federal Rule 23(a)(3)

${ }^{24}$ One obvious reason is that defendants' counsel do not often object to use of a class suit. Reasons for their failure to object might include: (1) willingness to have the matter decided as to all the class in one litigation; (2) belief that all members of the class would be concluded by a result adverse to them; and (3) lack of concern with the matter because of concentration on the substantive questions presented by the litigation. The major part of the defense will go to the issue of legality of the segregation. If the defendant is successful with his substantive arguments, there is no need to raise the procedural question.

${ }^{25} 104$ F. Supp. 848 (D.C. Mo., 1952).

${ }^{26}$ Tbid., at 857.

27339 U.S. 629 (1950).

${ }^{3} 235$ U.S. 151 (1914).

29305 U.S. 337 (1938).

${ }^{80}$ McCabe v. Atchison, T. \& S. F. Ry. Co., 235 U.S. 151 (1914), was a case in which five Oklahoma Negroes sought to enjoin certain railways from complying with an Oklahoma statute which provided that the railways maintain separate facilities for Negro passengers. The Court held the constitutional right "personal" in response to defendants' argument that it was not obliged to carry dining and sleeping cars for Negroes because of the small volume of Negro 
makes express provision for use of the class suit where "the character of the right sought to be enforced for or against the class is ... (3) several. ..."

An Alabama federal district court, in Mitchell $v$. Wright, ${ }^{31}$ has held the class suit device inappropriate in an action to enjoin the registrar of voters of Macon County from refusing to register Negroes solely because of race. Because "[r]egistration is an individual matter," ${ }^{32}$ the court held that it could not determine the question of unconstitutional discrimination by groups or classes. The argument was made that since there are certain special qualifications required for registration, a class suit is improper. This position apparently rests on the fact that it was not shown that there were other Negroes who met the qualifications. It is clear, however, that there are some qualifications on every right given by the state. The right to use recreational facilities, for example, is conditional on using them in an orderly manner, and is dependent on certain health and cleanliness qualifications. Therefore, the court's argument regarding qualifications would prove that the use of the class action device to enforce any civil or political right is infallibly improper, since all such rights carry some qualification.

There is another interesting consideration involved in Mitchell v. Wright and Williams v. Kansas City. In both of those cases, the courts seem to require preexisting proof of discrimination before conceding the existence of the class. In the Mitchell case, the court said that the mere allegation of discrimination against Negroes other than those named as plaintiffs would not suffice to put them in a class with the named plaintiffs. First, there must be a finding that there was discrimination against each Negro, and "only after such finding, if true, would that person become a member of such class." ${ }^{\prime 3}$ The Williams court also held that a showing of discrimination against others than the named plaintiff was a prerequisite to the use of the class suit device. The court said: "Such proof is essential to the individual plaintiffs' theory of the action," 34 i.e., the class action theory. Requiring proof of discrimination against the class before allowing the plaintiff to sue for the benefit of the class is like requiring that a plaintiff in a tort action prove that he was damaged before conceding that he has

traffic: "[Such an argument] makes the constitutional right depend upon the number of persons who may be discriminated against, whereas the essence of the constitutional right is that it is a personal one.... It is the individual who is entitled to equal protection of the laws. ..." Ibid., at 161. In Missouri ex rel. Gaines v. Canada, 305 U.S. 337 (1938), the Supreme Court held that the question of whether other Negroes, like the plaintiff, desired to enter the University of Missouri Law School was immaterial to the plaintiff's right to be admitted. The Court said that "petitioner's right was a personal one. It was as an individual that he was entitled to equal protection of the laws, and the State was bound to furnish him within its borders facilities for legal education substantially equal to those which the State there afforded for persons of the white race, whether or not other Negroes sought the same opportunity." Ibid., at 351. Sweatt v. Painter, 339 U.S. 629 (1950), restates the proposition that the individual is entitled to equal protection apart from his group connection.

s1 62 F. Supp. 580 (D.C. Ala., 1945).

32 Ibid., at 582.

3104 F. Supp. 848, 857 (D.C. Mo., 1952). 
standing to sue. It would seem that the claim of discrimination against the class should itself justify the use of the class action device.

Counsel for the plaintiffs in the Mitchell case had referred the court to McDaniel v. Board of Public Instruction. ${ }^{35}$ In that case the plaintiff brought suit for himself and others similarly situated for a declaratory judgment and an injunction to restrain the Board of Public Instruction from paying lower salaries to colored teachers. The $M c D a n i e l$ case held that the action was a class action authorized by Federal Rule 23. The court in Mitchell $v$. Wright distinguished the $M c D a n i e l$ case on the grounds that in McDaniel the class involved was sufficiently definite to admit of identification, while in the present case the class was diffuse and uncertain of identity. The requirement of definiteness (although, for reasons discussed below, of doubtful validity) finds some justification in the rule of Hansberry v. Lee. ${ }^{36}$ There, the Supreme Court held that a class action could effectively be maintained only in the certainty that the interests of the class members are all friendly to the object of the litigation. Definiteness as to the identity of the class membership might be thought to be a prerequisite to such certainty, if such certainty is at all possible.

This position suggests the necessity of a breakdown of the cases in terms of the definiteness of the classes involved, and the Mitchell court, in distinguishing McDaniel, appears to hint at the potentialities of this approach. Such a breakdown might begin at the point of least definiteness in cases where the alleged discrimination affects an entire group and requires of them no special relationship to the state, except as citizens. The ordinary case involving segregated municipal facilities would be an example. The breakdown could continue with cases in which, although no contractual relationship exists between the class and the state, the former is more definite and readily ascertainable by virtue of the fact that its members are required to have demonstrated that they conform to certain qualifications placed upon the right asserted. The Gray case, ${ }^{37}$ involving admission to a university, is an illustration. The last group in such a breakdown would consist of those cases in which the plaintiff class has a contractual relationship with the state such as that of employment as in the McDaniel case. ${ }^{38}$ Having established an ascending order of definiteness, and conceding the diffculty of drawing the lines of distinction in every case, it might be argued in the light of the certainty requirement of Hansberry v. Lee that the class suit device may properly be used only where the class itself is reasonably definite and capable of ascertainment. Thus, where the members of a plaintiff class are prom-

25 39 F. Supp. 638 (D.C. Fla., 1941).

${ }^{36} 311$ U.S. 32 (1940). See discussion part III infra.

37 Gray v. Board of Trustees, 342 U.S. 517 (1952).

${ }^{28}$ The contractual relationship would not necessarily have to be with the state. In Tunstall v. Brotherhood of Locomotive F. \& E., 148 F. 2d 403 (C.A. 4th, 1945), the plaintiff class consisted of certain employees of the Louisville \& Nashville Railroad. The members of the class in System Federation No. 91 v. Reed, 180 F. 2d 991 (C.A. 6th, 1950), had certain rights by virtue of their employment. Cases of this sort would fall within the category outlined. 
isees under a contract with the defendant, certainty as to their number and identity would be very great and use of the class suit device eminently proper. Where, on the other hand, the class sought to be represented numbered all the Negroes in the community, or perhaps all the Negro school children, certainty would be at a minimum and use of the class action doubtful. The special qualification cases would fall somewhere between these two extremes, propriety of the class action perhaps depending upon the stringency of the qualifications.

It may be said on the other hand that certainty as to those who constitute the class is not a prerequisite to maintaining a class action. According to Federal Rule 23, the class action device is available to classes with "numerous" membership. The Rule itself does not contain a requirement that the membership of the class be definite-i.e., certain in the sense that the members can be named-and the provision that a class action can be used for the benefit of classes with numerous members gives weight to the proposition that certainty as to membership is not required. Nevertheless, it must be admitted that the courts speak frequently of a "definiteness" requirement. It seems, however, that "definiteness" is not generally intended to mean certainty as to who might be able to take advantage of the result of the litigation, but rather a certain delineation as to the requirements for membership in the class.

In this sense, the definiteness requirement can be met easily by the plaintiff class in any antisegregation litigation: all members of the plaintiff class are certain to possess the racial, religious, or national characteristics which have made them the object of special treatment. If the group complaining is definite enough to be segregated from the rest of the community, it would seem that the members should have enough common characteristics so that a class action could be conducted on their behalf. Both legislative and administrative policies are directed at the class in terms of those characteristics. If the state treats members of a certain minority group as a group in fact by making it the object of ordinance or statute, this is some indication that the group can be treated as such for purposes of civil procedure.

In Parker v. University of Delazvare, ${ }^{39}$ the plaintiffs were suing for themselves and others similarly situated to restrain the university authorities from enforcing a trustees' ruling denying them admission because of their racial status. The defendants contended that the class was not sufficiently well-defined to be able to maintain a class action. The court disagreed:

Those Delaware Negroes who are legally interested in obtaining a college education and legally interested in a determination of their constitutional right with respect to admission to the University constitute a definite class within the meaning of the Rule of Court $^{40}$ governing class actions. Indeed, the Trustees by their ruling have created the class, and there is a certain irony in the suggestion of the Trustees' counsel that the class excluded is not sufficiently well-defined.at

3975 A. 2 d 225 (Del. Ch., 1950).

${ }^{30}$ Rule 23 of the Delaware Court of Chancery is the same as Federal Rule 23.

if $75_{4}^{7} \mathrm{~A} .2 \mathrm{~d}$ at 227. 
III

The broad issue concerning the effects of a decree on unnamed members of the class in antisegregation suits may be broken down into two fundamental questions: first, whether any member of the represented class has standing to enforce a favorable decree; second, whether the unnamed members of the class are precluded by an unfavorable decision from subsequently raising the question litigated in the class suit. ${ }^{42}$

The Supreme Court held, as early as $1853,{ }^{43}$ that the results of a class action were binding upon all members of the class. The Court seemed to ignore the last sentence of old Equity. Rule 48 which provided that in class actions "the decree shall be without prejudice to the rights and claims of absent parties." There was, however, much confusion about the binding effect of the decree on the unnamed members of a class until the decision in Supreme Tribe of Ben-Hur v. Cauble. ${ }^{44}$ Prior to the Ben-Hur decision, Equity Rule 48 had been replaced by Rule 38 of the more recent Equity Rules, and the sentence regarding the rights and claims of absent parties was omitted. An apparent contradiction existed between the equitable doctrine that the members of a class fairly represented in a class action would be bound by the decree and the constitutional doctrine announced in Pennoyer 0 . Neff, ${ }^{45}$ to the effect that the due process clause of the Fourteenth Amendment made it impossible to bind one by an action to which he was not a party. But in the Ben-Hur case, the Supreme Court held that, in the federal courts, the results of the original class suit would bind the unnamed members of the class represented. The Court said:

If the federal courts are to have the jurisdiction in class suits to which they are obviously entitled, the decree when rendered must bind all of the class properly represented... . The parties bringing the suit truly represented the interested class. If the decree is to be effective and conflicting judgments are to be avoided all of the class must be concluded by the decree. ${ }^{46}$

The Ben-Hur doctrine was evidently intended to apply to all class actions. The decree or any collateral matter decided, whether favorably to the class or not, could not again be disputed by any of the members of the class. The contradiction between Equity Rule 38 and the doctrine of Pennoyer v. Neff appeared to have been resolved.

In Hansberry v. Lee, ${ }^{47}$ however, the Supreme Court gave some new indications of its view on the binding effect of class suits on members of the class. Both the plaintiffs and the defendants in the Hansberry case were owners of certain parcels of land on which there were covenants prohibiting the sale of such plots to Negroes. The plaintiffs sought to enjoin a breach of the covenants. The defendants asserted that the covenant was not valid because the requisite number of

12 Both of these questions would be thought to come under the concept of res judicata. The reason for the division into two questions appears below.

${ }^{13}$ Smith v. Swormstedt, 16 How. (U.S.) 288 (1853).
14255 U.S. 356 (1921).
1595 U.S. 714 (1877).
${ }^{45} 255$ U.S. 356, 367 (1921).
17311 U.S. 32 (1940). 
lot owners in the affected area had not signed the agreement. The plaintiffs alleged that that question had been decided in the plaintiffs' favor in a prior litigation in which the present defendants had been represented as a class and by which they were now bound. The earlier action had been brought on behalf of the property owners in the restricted area to enforce the agreement and the fact that the required number of property owners had signed the agreement had been stipulated by the parties. The Court in the Hansberry case held that, although the present defendants were members of the class represented as seeking enforcement in the prior litigation, they could not now be bound by the results of the earlier action. It would be improper, said the Court, "to hold that all those who are free alternatively either to assert rights or to challenge them are in a single class, so that any group, merely because it is of the class so constituted, may be deemed adequately to represent any others of the class in litigating their interests. ..." ${ }^{48}$ The Court reasoned that because the interests of the representatives were not necessarily or even probably the same as the interests of the class, the absent parties had not been afforded that measure of protection which due process requires, and hence were not bound by the holding in the prior litigation. The Court declined to overrule earlier decisions, such as Ben-Hur, which held that the matters decided in a class action were res judicata as to the entire class represented. But by the requirement that all of the class have the same interest in the result of the litigation, the Court appears to have said, in effect, that the class is never bound by the results of a class action, since there probably exists no group of people whose interests are all the same. There is some doubt that an attempt to bind a class by the results of an unfavorable decree would succeed, in view of the decision in Hansberry v. Lee. Whether members of a class could seek enforcement of a favorable decree is not entirely clear from the Hansberry decision.

When Federal Rule 23 was promulgated, it divided the class action into three categories. According to Professor Moore, one of the draftsmen of the rules, class actions are divided into the true, the hybrid, and the spurious, the requirements for each, and their legal consequences, being different. ${ }^{49}$ The so-called "hybrid" class suit will not be considered here because it is not important to our discussion. ${ }^{50}$ The true class suit is one in which it would be necessary, except for the use of the class action device, for all of the members of the class to join. ${ }^{.1}$ All of the matters decided in the true class suit are said to be res judicata as to the represented class and its adversary. ${ }^{52}$ The spurious class suit, on the other hand,

48 Ibid., at 45.

49 Moore, op. cit. supra note 18 , at 3,434-70.

${ }^{50}$ The hybrid class suit is provided for by Federal Rule 23(a)(2): a class suit is proper when the character of the right sought to be enforced for or against the class is "several, and the object of the action is the adjudication of claims which may or do affect specific property involved in the action." Since there is ordinarily no specific property involved in antisegregation litigation, paragraph (a)(2) of Rule 23, and the type of class suit it provides for, will not be considered here.

${ }^{51}$ Moore, op. cit. supra note 18 , at 3,435 . This seems to be similar to the old equity requirement for a class suit. Story's Equity Pleadings $\$ \S 94-135$ (10th ed., 1892).

52 Moore, op. cit. supra note 18 , at 3,457 . 
is merely a permissive joinder device, and the members of the class are affected by the results of the suit only if they actually become parties. ${ }^{53}$ Hence, under Moore's analysis, in order for an antisegregation suit to be enforceable by those members of the class who were not originally parties to the action, it would have to be denominated a true class action. Moore explicitly denies that the unnamed members of the class represented in a spurious class suit should have any right to enforce a favorable decree..$^{54}$ To put the antisegregation suit into Moore's true class action category, it must be said that were it not for the class suit device all of the members of the class would have to be joined as parties to the action. This would be to say that individuals have no power to enforce their constitutional right to equal treatment solely on their own behalf. Because of the "personal" and individual nature of constitutional rights, this position seems untenable. ${ }^{55}$ Thus, if the antidiscrimination class action is to fit into any of Moore's classifications, it must be a spurious class suit, in which case unnamed members of the class would thereafter be barred from enforcing a favorable decree..$^{56}$

Professor Chafee, in "Some Problems of Equity," came to conclusions very different from those of Professor Moore. Chafee suggests that the class suit be divided into two categories. ${ }^{57}$ The "Solid Class Suit" would be comparable in its binding effect on unnamed members of the class to Moore's true class suit. ${ }^{58}$ The "Invitation To Come In" would be the counterpart of the spurious class action, as respects its nonbinding character. ${ }^{59}$ The basic difference between Chafee's analysis and that of Moore is as to the necessary requisites for including any particular class suit in the one category or the other. ${ }^{60} \mathrm{Admitting}$ that "the line between Solid Class Suits and Invitations To Come In cannot be definitely stated," Chafee enumerated the following factors as tending to place an action within the Solid Class Suit category: the existence of a common question, the policy in favor of settling the issue once and for all, and the lack of distinctive individual interests of members of the class. Chafee continues: "Among contrary factors are the existence of strong reasons for keeping individual claims from being barred by the failure of the group suit. . . ."262 It is difficult to say whether all considerations would dictate that the antidiscrimination class suit falls within the Solid Class Suit category, or in that of Invitations. An antidiscrimination claim seems to be one particularly amenable to being settled by a single class

53 Ibid., at 3,465.

st Ibid., at 3,475-76.

${ }^{55}$ See note 30 supra.

${ }^{58}$ In Jinks v. Hodge, 11 F.R.D. 346, 347 (D.C. Tenn., 1951), an action brought in behalf of the members of a labor union against the chief of police for alleged deprivation of civil rights, the court said: "If a class action at all, it is what Professor Moore in his Federal Practice calls a Spurious Class Suit, which is a permissive joinder device. This is based on Rule 23(a)(3)."

${ }^{57}$ Chafee, Some Problems of Equity 199-295 (1950).

${ }^{68} \mathrm{Ibid}$., at $280 \mathrm{et}$ seq.

59 Tbid.

${ }^{80}$ Moore's requirement for the true class suit is that the members of the class would have been required to join, except for the class action device. All other class actions, except those which are "hybrid" because of specific property involved, would have to be "spurious."

${ }^{61}$ Chafee, op. cit. supra note 57 , at 282.

62 Mbid. 
suit, because of the group nature of the alleged wrong. If the controlling considerations are those tending to put the antisegregation suit into the category of the Solid Class Suit, the result would be res judicata for all members of the class. The members would then be able, according to Chafee's analysis, to take advantage of a favorable decree and would doubtless be bound by an unfavorable determination.

The Court of Appeals for the Sixth Circuit, in System Federation No.91 v. Reed ${ }^{63}$ has taken the position that a decree in an antisegregation class suit is enforceable by members of the class not named in the original action. The first action was brought by some nonunion railroad machinists for the benefit of "all members of the craft of machinists employed by the [Louisville and Nashville] railroad" ${ }^{4}$ against both the railroad and the union serving as bargaining agent for the machinists. Plaintiffs sought a declaratory judgment and a perpetual injunction restraining the defendants from discriminating against the members of the plaintiff class because they were not union members. The injunction was granted and, subsequently, the plaintiff in the present action brought contempt proceedings against the defendants for violation of the injunction. Although the present plaintiff had not been one of the plaintiffs named in the original action, the district court enforced the earlier decree for his benefit. The Court of Appeals affirmed, saying: "The issues on this aspect of the case, therefore, are: (1) whether the original class action was a true class action; and (2) whether Reed had a right to intervene after decree in that action." The Court went on to consider the confusion arising out of the three-fold division of the class action device under Rule 23: "Much confusion has been created by the use of the nomenclature applied to class actions as true, spurious, or hybrid. . . . Analysis of class actions as true, spurious and hybrid, has been criticized as 'traditional but useless."' 65 The court concedes that in order for the intervenor to be able to enforce the decree, the original action must have come within Rule 23(a)(1). "Certainly, under [the present] circumstances, the "character of the right sought to be enforced for . . . the (plaintiff) class, is . . joint, or common,' within the clear intendment of Rule 23(a)(1)."66

The System Federation case was decided on the basis of the provisions of Rule 23, but neither Moore's analysis nor that of Chafee was followed completely. The Court accepted Moore's analysis to the extent of holding that unnamed members of the class will be bound only if the action falls within 23(a)(1). But in deciding that the original action did fall within 23(a)(1), the Court failed to apply Moore's rule that a class action is "true" only when joinder of all members of the class would have been necessary except for the class action device. Nor did the Court attempt to apply Chafee's general criteria regarding cases to be treated as Solid Class Suits. The holding was simply that the rights involved were in some sense "joint, or common," and thus fulfilled the literal require-

${ }^{63} 180$ F. 2d 991 (C.A. 6th, 1950).

64 Ibid., at 992.

65 Ibid., at 996.

so Ibid., at 997. 
ments of 23(a)(1). The Court did not attempt to distinguish "common" rights provided for by 23(a)(1) from "several" rights when there is a common question involved, as provided for by 23(a)(3). It would therefore seem, under the loose criteria set up by System Federation, that any right which all members of the class possessed would be a "common" right. Since segregation is a wrong, if at all, "common" to all members of the segregated class, the broad language of System Federation would appear to place the antisegregation class suit well within the terms of 23(a)(1), and hence render a determination binding upon and enforceable by unnamed group members.

Under the ordinary requirements of mutuality or equality between parties to an action, it might be said that if a favorable result would inure to the benefit of unnamed members of the class, unnamed members should be bound by an adverse decision as well. It has been suggested by Kalven and Rosenfield ${ }^{67}$ that the unnamed members of a class should be allowed to take advantage of a favorable decree in litigation brought in their behalf without, on the other hand, being bound by an adverse judgment. Prevailing ideas about the necessary mutuality of res judicata would appear to invalidate this suggestion. This feeling was well expressed by Chafee in his criticism of Kalven and Rosenfield's discussion:

Going back to the idea that the outsiders can participate in a victory without bearing the burdens of defeat, I shall simply point out its total inconsistency with the longsettled rule that res judicata always cuts both ways. As with William James' cocktail, he must take the bitter with the sweet-or else not drink any of it. ${ }^{68}$

The answer that Kalven and Rosenfield make to the mutuality argument is simply that there is no failure of mutuality in a class suit even though the decision be held binding on the class only when it is favorable to the class. The reasoning behind Pennoyer v. Neff, ${ }^{69}$ said these authors, supports this view. One should not be bound without having had his day in court, and the unnamed members of the class have clearly not had theirs. Their adversary, however, has had an ample opportunity to present his case in the original action. In terms of equal opportunity, therefore, mutuality would seem to require that the class be bound only when it has no further need to litigate, that is, only when the decision is favorable to persons not before the court.

In the context of the antisegregation class suit, it should also be pointed out that while the only effective measure of protection for the class consists in allowing all members to enforce the decree, the defendants will be sufficiently protected by the ordinary operation of stare decisis. The decision in the original class suit, if favorable to the defendant, would have overwhelming precedental effect as to the legal issues there concluded. Because the defendant is a single, concrete individual (usually the state), stare decisis is an adequate guarantee of finality to it. (At the same time the members of the plaintiff class are not injured by the operation of stare decisis to the extent that they would be if a prior decision

${ }^{67}$ The Contemporary Function of the Class Suit, 8 Univ. Chi. L. Rev. 684 (1941).

${ }^{68}$ Chafee, op. cit. supra note 57 , at 280.

6995 U.S. 714 (1877). 
were given the effect of res judicata against them, since support given to a state practice by a judicial holding cannot be said importantly to alter the status of members of the class discriminated against.) On the other hand, for the reasons suggested in Part I above, and particularly because the class is numerous and scattered, enforceability of a favorable decree provides the only remedy adequate to the needs of the group. In the sense, then, that precedent provides the defendant with sufficient protection when a later action is brought against it, no offense would be done to mutuality should the class be held bound only when the original action results in a favorable decree.

It should be noted here that to bind the members of a class by an unfavorable decree would be to freeze their political as well as their legal rights by judicial order. Yet the major part of the civil rights battle is traditionally fought in the political, not the legal, arena. A legal action brought to secure certain civil rights to a minority group should not have the effect of making it more difficult for the group to combat abrogation of those rights, if the action be unsuccessful. Because the rights asserted in antidiscrimination cases are both important and personal, it would seem improper to bind the class by an action brought by an unappointed (and possibly incompetent) representative. Since the rights are based on the Constitution, it is doubtful whether they should be denied to the class by a procedural device.

\section{IV}

The basic rationale behind the origin of the class action device no longer applies in those cases brought to combat discrimination. The reason that class actions were allowed in the chancellor's court was that a strict application of the rule that all parties interested in an action must be joined might prevent substantial justice where necessary parties were numerous or inaccessible. Under any interpretation, it is clear that Federal Rule 23 extends beyond the equity practice. Should it be maintained, then, that the rule of the chancellor on binding the class is still of current value? It is submitted that the decision to be made on the res judicata effect of class actions on the unnamed members of the class is a policy decision, and not one to be made on the basis of the requirements of the equity-developed device.

The class suit is a device useful for and adaptable to many situations not in contemplation when it originated in the chancery court. As provided for by Rule 23, the class suit is eminently suited to the purpose of affording relief to racial, religious and national groups which have been made the objects of segregation. This comment has attempted to show the difficulties and advantages of the class suit in antisegregation litigation. More specifically, the effect of the class action on the unnamed members has been considered. The questions whether the members of a class can enforce a favorable decree, and whether an unfavorable result will bind them, have likewise been discussed. In coming to the conclusion that the remedy for unlawful segregation will be adequate only if a favorable decree is enforceable by any member of the class, it has been suggested that this does not necessitate binding the class by an unfavorable deci- 
sion. The usefulness of the class action device as providing an adequate group remedy will depend upon recognition by the courts of the adaptable and multipurpose nature of the class suit device.

\section{LIMITS ON CONGRESSIONAL INQUIRY}

\section{RUMELY V. UNITED STATES}

In 1949, Congress created the House Select Committee on Lobbying to investigate "all lobbying Activities intended to influence, encourage, promote or retard legislation." The Select Committee subpoenaed defendant, executive secretary of the Committee for Constitutional Government (CCG), an organization engaged in publishing and distributing to the general public books and pamphlets pertaining to national affairs. Defendant appeared before the Select Committee but refused to obey the Committee's order to reveal the names of persons from whom the CCG had received funds. ${ }^{2}$ Defendant was indicted and convicted under a statute making it a misdemeanor for a witness to refuse to answer "any question pertinent to the question under inquiry" by a congressional committee. ${ }^{3}$ On appeal, held, reversed. Rumely v. United States. ${ }^{4}$

The Court of Appeals stated that publicizing the names of purchasers of books and other literature "is a realistic interference with the publication and sale of those writings,"and thus a violation of the free speech and free press clauses of the First Amendment. This violation is not counterbalanced by any public danger posed by the CCG that might create a necessity for congressional inquiry. Were the empowering statute of the Select Committee construed to permit the Committee to investigate efforts to influence public opinion at large, serious constitutional questions would be raised. In order to avoid these questions, the court invoked dictionary definitions to limit the meaning of "lobbying activities" in the statute to direct contact with legislators. Given this interpretation, the court found that the Select Committee had exceeded its power in questioning Rumely concerning the names of CCG's subscribers, and that Rumely consequently was within his rights in refusing to supply the information. ${ }^{5}$

The Rumely case is not based upon objections to the procedure of the investi-

1 H.R. Res. 298, 81st Cong. 1st Sess. (1949).

2 It was maintained by the government that the CCG was attempting systematically to evade the registration provisions of the Lobbying Act, 60 Stat. 839 (1946), 2 U.S.C.A. $\$ \$ 261-$ 70 (1951). This was done by accepting as payment for literature money that was in fact a contribution. The court dismissed this argument on the ground that the question of subterfuge was not before the trial court. For a description of the financing of the CCG, consult Schriftgiesser, The Lobbyists 161-66 (1951).

352 Stat. 942 (1938), 2 U.S.C.A. \$192 (1951).

197 F. 2 d 166 (App. D.C., 1952), aff'd, 73 S. Ct. 543 (U.S., 1953). Discussion in the text is limited to the Court of Appeals decision.

- The Supreme Court, in affirming, followed a similar line of reasoning. Douglas, J., concurring, rejected the narrow interpretation of lobbying as contrary to the scope intended by Congress, and concluded that the "potential restraint" on speech and press imposed by the inquiry was an infringement of the First Amendment. 